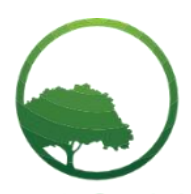

Research in Business \& Social Science

\title{
The role of relationship marketing to building loyalty on bank customers
}

Sudirman Zaid@

Crossref

Faculty of Economic and Business, Halu Oleo University, Kendari, Indonesia

\begin{tabular}{l} 
A R T I C L E I N F O \\
\hline Article history: \\
Received 17 March 20 \\
Received in revised form 05 April 20 \\
Accepted 12 April 20 \\
\hline Keywords: \\
Relationship Marketing; \\
Communication; Handling Problem; \\
Trust; Commitment; Loyalty. \\
JEL Classification: \\
M31
\end{tabular}

\begin{abstract}
A B S T R A C T
This study aims to test the role of relationship marketing on customer loyalty. The research used quantitative approach with the survey method. Population of the research is all customer of BRI Bank in Kendari City Indonesia, where the respondent in this research are 77 customer. The cross sectional data was collect to measure of each variable research. Analysis research used Partial Least Squared $(P L S)$ to test of the role of each relationship marketing variable to building customer loyalty. The results explained that; (a) communication has a significant role on trust; (b) handling problem has a non-significant role on trust; (c) communication has a significant role on commitment; (d) handling problem has non-significant role to commitment; (e)trust has a significant role on commitment; $(f)$ communication has a non-significant role on loyalty; $(g)$ handling problem has a non-significant role on loyalty; ( $h$ )trust has a significant role to customer loyalty; and (i) commitment has a significant role on loyalty. This study also found that the problem handling variable has no role in building customer loyalty. This study concludes that the BRI Bank is still not good in handling problems with their customers and the variables of trust and commitment play a significant role in mediating the role of communication in building customer loyalty.
\end{abstract}

() 2020 by the authors. Licensee SSBFNET, Istanbul, Turkey. This article is an open access article distributed under the terms and conditions of the Creative Commons Attribution (CC BY) license (http://creativecommons.org/licenses/by/4.0/).

\section{Introduction}

The potential of the banking industry in Indonesia continues to grow so that foreign and local companies compete to enter the banking market in Indonesia. This condition causes intense competition in the Indonesian banking industries. Various innovations and changing situations force banking companies to adapt to survive and win market opportunities. To capture market opportunities in the banking industry, the main thing that needs to be done is to increase the company's credibility. However, to increase the company's credibility is not easy, the right strategies and innovations are needed so that the goals and objectives can be achieved optimally. In the current era of globalization, competition in the banking industry does not only come from fellow banking companies, but several other industries engaged in finance also work on the same market share as banks? Based on the writer's observation, PT. BRI Bank Tbk has a good relationship marketing with their customer. This can be seen from the existence of BRI Bank which is still in great demand today.

Relationship Marketing is how a company finds customers, tries to know customers, relates to customers, tries to convince customers, gets what customers want, not only in the form of products but from every aspect related to customer (Cater \& Cater, 2010). Relationship Marketing here emphasizes maintaining and always improving relationships with existing customers rather than looking for new customers (Sundaramoorthy \& Sachithanantham, 2016). Relationship marketing including trust, commitment, communication, competence and handling problem has role on loyalty (Moosavi et al, 2013; Hurriyati, 2008). Relationship Marketing which consists of trust, commitment, communication, and handling problem has role on customer loyalty (Gina \& Widyastuti, 2013). Relationship marketing including, bonding, trust, communication, satisfaction and commitment has role on customer loyalty (Laith \& Nahla, 2010).

* Corresponding author. ORCID ID: 0000-0002-5977-5623

(C) 2020 by the authors. Hosting by SSBFNET. Peer review under responsibility of Center for Strategic Studies in Business and Finance. https://doi.org/10.20525/ijrbs.v9i3.657 
In overall, the objectives of this research is aims to determine the role of relationship marketing variables, consisting; communications, problem handling, trust, and commitment in building customer loyalty at BRI Bank in Kendari City. And then, the research questions was built in this research are;

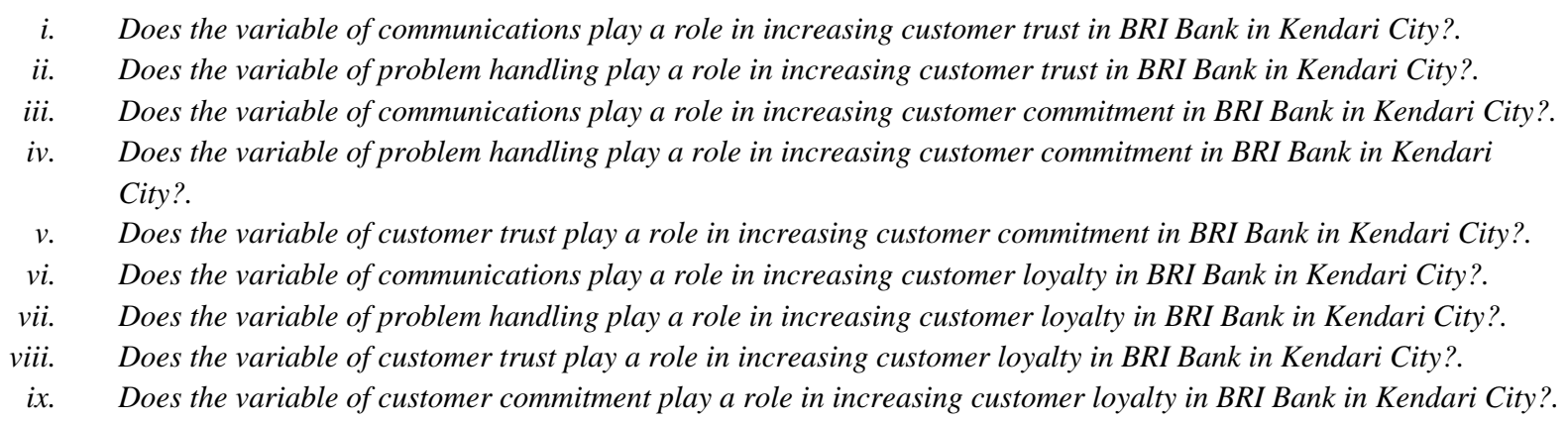

In achieving research objectives and to answer research questions, this study uses a survey method. The survey method was conducted to collect data on BRI Bank customers in Kendari City by distributing a research questionnaire containing their responses to the research variables. The results of data collection are then analyzed to see how the role of each relationship marketing variable is in building customer loyalty on BRI Bank in Kendari City.

The reminder of this study is organized as follows. The next section provides a review of extant literature. The third section discusses the methodology and data. Finally, conclusions and implications of the study are presented in the final section.

\section{Literature review}

The marketing process starts with the needs and desires that want to be satisfied. The increasingly diverse needs and desires of consumers are a challenge for marketers in the marketing world. Marketing is actually much broader than sales (Chandra,2002). Marketing is a process of perceiving, understanding, stimulating and meeting the needs of specifically selected target markets by channeling the resources of an organization to meet those needs (Payne, 1993). Marketing is the process of planning and implementing conceptions, pricing promotions and distributing ideas, service goods in order to satisfy individuals and organizations (Chandra,2002). Marketing is a social process by which one individual and group process gets what they need and want by creating, offering, and freely exchanging valuable products and services with other parties (Kotler, 2010).

Relationship marketing is a process of creating, maintaining, and enhancing strong and high-value relationships with customers and other interested parties (Kotler \& Armstrong, 2006). Relationship Marketing is a relationship that is not detrimental, even Relationship Marketing is a relationship that is interdependent, there is trust, cooperation and partnership (Yanita \& Anik, 2016). Relationship Marketing is a philosophy in carrying out a business orientation focused on improving and maintaining existing / old customer service, compared to finding new customers (Zeithaml et al, 2010). In service companies, the application of relationship marketing provides several potential benefits as follows: Direct benefits in the form of lower costs (such as marketing costs, administrative costs, costs to get to know consumers and others), customer loyalty, premium price for superior service and word of mouth communication (Hasanuddin, 2009). Indirect benefits include employee retention, because people usually prefer to work in companies that have loyal customers. The key to goodness in supporting relationship marketing, such as trust, commitment, conflict handling, and communication or sharing secrets (Ndubisi, 2007). This has been related in studies of consumer loyalty.

Loyalty is in-depth customer commitment to re-subscribe or repurchase future products or services, even though the influence of the situation and marketing efforts have the potential to cause behavior change (Alma \& Hurriyati, 2008; Hurriyati, 2008). Customer loyalty is an arrangement of five elements namely overall customer satisfaction, low or irregularity of the level of satisfaction canceling customers for the company to get customer loyalty, customer commitment to create repeat purchases in a relationship with the company, desires customers to recommend the company to others, as well as customer durability to move to competitors (Cater $\&$ Cater, 2010).

Relationship marketing including trust, commitment, communication and handling problem has role on customer loyalty (Gina \& Widyastuti, 2013). Relationship marketing including bonding, trust, communication, satisfaction and commitment has role on customer loyalty (Laith \& Nahla, 2010). Relationship Marketing including joint profit, commitment, communication and truth has a role on customer loyalty (Wardhani et al, 2017). Based on all that previous research, in this reasearch there are four dimensions of relationship marketing that will be examined for their roles on customer loyalty, namely trust, commitment, handling problem and communication.

\section{Hypothesis development}

Based on the above framework, the authors formulated several hypotheses in this research as follows: 
H1: Communication have a significant role on trust.

$\mathrm{H} 2$ : Handling problems have a significant role on trust.

H3: Communication have a significant role on commitment.

H4: Handling problems have a significant role on commitment.

H5: Trust have a significant role on commitment.

H6: Communication have a significant role on loyalty.

H7: Handling problems have a significant role on loyalty.

H8: Trust have a significant role on loyalty.

H9: Commitment have a significant role on loyalty.

\section{Research methodology}

The location of this study is in the Kendri City Bri Bank, the population of this study is all BRI bank customers in the city of Kendari, where in 2016 there were 1,142 people. The number of samples in this study was determined using the Slovin formula. Large population, the researchers set the number of samples with the Slovin formula the amount can be calculated as follows:

$$
\mathrm{n}=\mathrm{N} /(1+\mathrm{N}(\mathrm{d}) 2)
$$

Information:

$\mathrm{n}=$ number of samples

$\mathrm{N}=$ population size

$\mathrm{d}=$ margin of error

Based on the population above, the number of BRI Bank customers in Kendari City in 2016 totaled 1,142 people, using a maximum margin of error of $11 \%$, so the number of samples in this study can be determined:

$$
\mathrm{N}=1.142 /(1+1.142(0.11) 2)=77 \text { person }
$$

To get the maximum results of the research, the type of data used in this study is qualitative and quantitative data. Qualitative data is data obtained in the form of information from agencies and other parties that are related to the problem that will be discussed in this study. Quantitative data is data obtained in the form of numbers that can be calculated. Partial Least Squared (PLS) analisys used to test hypothesis in this research.

Research variables were measured using indicators as follows; communication is measured by two indicators namely; [1] direct communication, and [2] indirect communication; problem handling are measured by three indicators, namely; [1] try to prevent problems from occurring, [2]quickly solve problems if they occur, and [3] solve problems together; trust is measured by four indicators, namely; [1] trust in handling customer complaints, [2] trust in fulfilling customer desires, [3] trust in providing true information, and [4] trust in honesty and morality; commitment is measured by four indicators, namely; [1] have emotional ties, [2] a high sense of belonging, [3] a feeling of pleasure when visiting, and [4] not influenced by other banks; loyalty is measured by four indicators, namely; [1] interest in repurchasing, [2] informing others about bank service performance, [3] word-of-mouth, and [4] cooperation.

\section{Results}

Bank Rakyat Indonesia was first established by Raden Aria Wirjaatmadja under the name Hulp-en Spaarbank der indlansche Bestuurs Ambtenaren or Bank of Assistance and Savings of Priyayi which is Indonesian (native). Hulp-en Spaarbank der indlansche Bestuurs Ambtenaren or Priyayi Bank of Indonesia (native) was established in Purwokerto on 16 December 1895, which was then made the anniversary of BRI Bank.

In conducting research, an instrument can be said to be valid if the instrument to be measured has benchmarks to be measured. In other words, the validity test is intended to determine the level of accuracy of the instrument used to measure the variables to be measured. In this study to test the validity of the instrument, the Pearson Product Moment Correlation analysis model was used at a significance level of a 0.05 . Meanwhile, to produce an index or validity coefficient number, the SPSS version 24 will be used. In this study the validity analysis was done by analyzing the results of the validity test through SPSS version 24 of the research instrument for communication variables (X1), problem handling (X2), trust (X3) and commitment (X4) as independent variables and loyalty (Y) as dependent variable. For more details, a summary of the results of the test of the validity of the research instruments is presented in Table 1 as follows: 
Table 1: Validity test results

\begin{tabular}{lllll}
\hline Research variable & Statement Code & Validity test & & \\
\cline { 2 - 5 } & & Correlation coefficient $(\mathrm{r})$ & Sig & information \\
\hline Communication $(\mathrm{X} 1)$ & $\mathrm{X} 1.1$ & 0,891 & 0,000 & Valid \\
& $\mathrm{X} 1.2$ & 0,911 & 0,000 & Valid \\
\hline Handling problems & $\mathrm{X} 2.1$ & 0,789 & 0,000 & Valid \\
$(\mathrm{X} 2)$ & $\mathrm{X} 2.2$ & 0,841 & 0,000 & Valid \\
& $\mathrm{X} 2.3$ & 0,855 & 0,000 & Valid \\
\hline Trust & $\mathrm{X} 3.1$ & 0,513 & 0,000 & Valid \\
$(\mathrm{X} 3)$ & $\mathrm{X} 3.2$ & 0,505 & 0,000 & Valid \\
& $\mathrm{X} 3.3$ & 0,418 & 0,000 & Valid \\
& $\mathrm{X} 3.4$ & 0,432 & 0,000 & Valid \\
\hline Commitment $(\mathrm{X} 4)$ & $\mathrm{X} 4.1$ & 0,723 & 0,000 & Valid \\
& $\mathrm{X} 4.2$ & 0,884 & 0,000 & Valid \\
& $\mathrm{X} 4.3$ & 0,803 & 0,000 & Valid \\
& $\mathrm{X} 4.4$ & 0,802 & 0,000 & Valid \\
\hline Loyalty & Y1 & 0,828 & 0,000 & Valid \\
(Y) & Y2 & 0,823 & 0,000 & Valid \\
& Y3 & 0,732 & 0,000 & Valid \\
& Y4 & 0,709 & 0,000 & Valid \\
\hline
\end{tabular}

Based on Table 1 above shows that the results of the validity test of all instruments have a correlation coefficient $(r) \geq 0.30$ with a significance value below 0.05 or $95 \%$ confidence level, so it can be interpreted that all statement items used as instruments in this research is valid.

Table 2: Reliability test results

\begin{tabular}{llll}
\hline Research variable & Code & Reliability Test & \\
\cline { 3 - 4 } & Statement & Cronbach Apha & Information \\
\hline Communication & X1.1 & 0,891 & Reliabel \\
(X1) & X1.2 & 0.885 & Reliabel \\
\hline Handling problems & X2.1 & 0,892 & Reliabel \\
$(X 2)$ & X2.2 & 0,893 & Reliabel \\
& X2.3 & 0,890 & Reliabel \\
\hline Trust & X3.1 & 0,887 & Reliabel \\
$(X 3)$ & X3.2 & 0,884 & Reliabel Reliabel Reliabel \\
& X3.3 & 0,886 & \\
\hline Commitment & X3.4 & 0,885 & Reliabel \\
$(X 4)$ & X4.1 & 0,887 & Reliabel Reliabel Reliabel \\
& X4.2 & 0,880 & \\
\hline Loyalty & X4.3 & 0,879 & Reliabel \\
$($ Y) & X4.4 & 0,882 & Reliabel Reliabel Reliabel \\
& Y1 & 0,888 & \\
& Y2 & 0,887 & \\
\hline
\end{tabular}

Based on Table 2 above shows that the reliability test results of all instruments have a crobach apha value $(\alpha) \geq 0.60$ so that it can be interpreted that all statement items used as instruments in this study can be trusted for their reliability.

In this study, to answer the problems and hypotheses proposed, the data analysis used is SmartPLS analysis on SmartPLS version 3 software using the Inner Model structural test. The results of Loading on the full model are based on structural model tests on SmartPLS 3. 


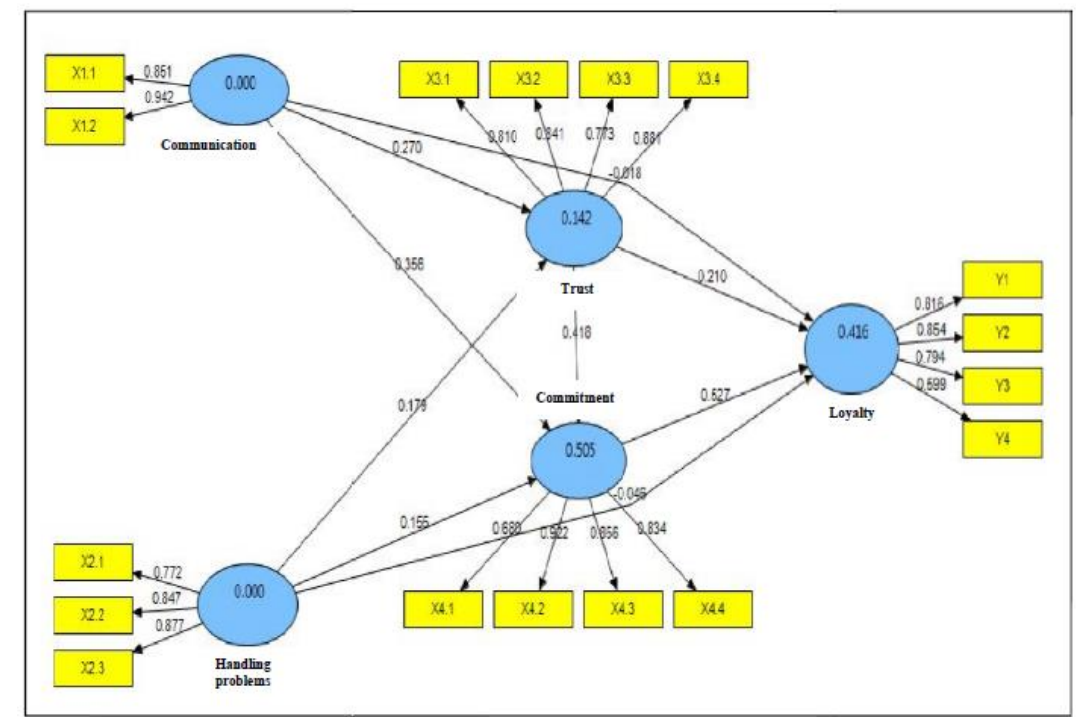

Fig. 1: Research model

\section{Hypothesis testing direct roles}

In this study, to answer the problems and hypotheses proposed, the data analysis used is SmartPLS analysis on SmartPLS software version 3 using the structural model test (Inner Model). The procedure in testing hypotheses on direct roles is by comparing the values of T-Test with T-Tables $(1,67)$. A hypothesis can be accepted if the T-Tset is greater $(>)$ than the T-Table. For more details can be seen in the following Table 3 :

Table 3: Path coefficient

\begin{tabular}{llllll}
\hline & $\begin{array}{l}\text { Original } \\
\text { Sample }\end{array}$ & $\begin{array}{l}\text { Sample } \\
\text { Mean }\end{array}$ & $\begin{array}{l}\text { Standard } \\
\text { Deviation }\end{array}$ & $\begin{array}{l}\text { Standard } \\
\text { Error }\end{array}$ & T Test \\
\hline Communication -> Trust & 0.2701 & 0.2855 & 0.1311 & 0.1311 & 2.0606 \\
\hline Problem Handling -> Trust & 0.179 & 0.2015 & 0.15 & 0.15 & 1.1933 \\
\hline Communication -> Commitment & 0.3557 & 0.3357 & 0.0844 & 0.0844 & 4.2162 \\
\hline Problem Handling -> Commitment & 0.1551 & 0.1815 & 0.1116 & 0.1116 & 1.3895 \\
\hline Trust -> Commitment & 0.4178 & 0.411 & 0.0773 & 0.0773 & 5.4042 \\
\hline Communication -> Loyalty & -0.0183 & -0.0185 & 0.1512 & 0.1512 & 0.1207 \\
\hline Handling Problems -> Loyalty & -0.0458 & -0.0321 & 0.1187 & 0.1187 & 0.3856 \\
\hline Trust -> Loyalty & 0.2103 & 0.2017 & 0.1145 & 0.1145 & 1.8376 \\
\hline Commitment -> Loyalty & 0.5272 & 0.5186 & 0.1222 & 0.1222 & 4.3155 \\
\hline
\end{tabular}

\section{H1: Communication have a significant role on trust.}

Based on table 3 above, it can be seen partial role between communications (X1) on the trust (X3) shows the original sample estimate value is 0.270 . The value of T-Test 2.061, this is greater than 1.67. This result indicates that communication has a significant role on trust of BRI Bank customers in Kendari City, so the first hypothesis is accepted.

\section{H2: Handling problem have a significant role on trust.}

Based on table 3 above, it can be seen partial role between problem handling (X2) on trust (X3) showing the original sample estimate value is 0.179 . T-Test value 1.193 is smaller than 1.67. This result indicates that problem handling has a non significant role on trust of BRI Bank customers in Kendari City so that the second hypothesis is rejected.

\section{H3: Communication have a significant role on commitment.}

Based on table 3 above, it can be seen the partial role between communications (X1) on commitment (X4) showing the original sample estimate value is 0.356 . T-Test value 4.216 is greater than 1.67. This result indicates that communication has a significant role on commitment of BRI Bank customers in Kendari City so that the third hypothesis is accepted. 


\section{H4: Handling problems have a significant role on commitment.}

Based on table 3 above, it can be seen partial role between problem handling (X2) on commitment (X4) shows the original sample estimate value is 0.155 . T-Test value 1.390 is smaller than 1.67 . This result indicates that problem handling has a non significant role on commitment of BRI Bank customers in Kendari City so that the fourth hypothesis is rejected.

\section{H5: Trust have a significant role on commitment.}

Based on table 3 above, it can be seen partial role between trust (X3) on commitment (X4) shows the original sample estimate value is 0.418 . T-Test value is 5.404 is greater than 1.67. This result shows that trust has a significant role on commitment of BRI Bank customers in Kendari City so that the fifth hypothesis is accepted.

\section{H6: Communication have a significant role on loyalty.}

Table 3 can be seen the partial role between communication (X1) on loyalty (Y) shows the original sample estimate value is $-0,018$. T-Test value 0.121 is smaller than 1.67. This result shows that communication has a non significant role on loyalty of BRI Bank customers in Kendari City so that the sixth hypothesis is rejected.

\section{H7: Handling problems have a significant role on loyalty.}

Table 3 can be seen partial role between problem handling (X2) on loyalty (Y) showing the original sample estimate value is - 0.046 . T-Test value 0.386 is smaller than 1.67. This result indicates that problem handling has a non significant role on loyalty of BRI Bank customers in Kendari City so that the seventh hypothesis is rejected.

\section{H8: Trust has a positive and significant role on loyalty.}

Table 3 can be seen the partial role between trust (X3) on loyalty (Y) shows the original sample estimate value is 0.418. T-Test value 5.404 is greater than 1.67. This result shows that trust has a significant role on loyalty of BRI Bank customers in the city of Kendari so that the eighth hypothesis is accepted.

\section{H9: Commitment have a significant role on loyalty.}

Based on table 3 above, it can be seen partial role between commitment (X4) on loyalty (Y) shows the original sample estimate value is 0.527 . T-Test value 4.316 is smaller than 1.67. This value result that commitment has a significant role on loyalty of BRI Bank customers in Kendari City so that the ninth hypothesis is accepted.

\section{Discussion}

The results of this research indicate that communication has a significant role on trust. Positive and significant influence means that good communication will have an impact on the high trust of customers, because good communication will make it easy for customers to obtain information about matters relating to the BRI Bank products that they use. The results of this study reinforce the results of research conducted by Morgan \& Hunt (1994); Dian (2014) that communication is the basis for the creation of trust. This research is also in line with what was delivered by Hasanuddin (2009) that companies that are not honest in providing information and services to customers will cause distrust of customers in the company and move to buy goods / services at rival companies. But this is different from the results of research conducted by Donney \& Cannon (1997), that communication does not affect customer confidence in sellers or companies.

The results of this study indicate that the handling of the problem has a positive and not significant role on trust. Positive influence means that handling problems has a direct role on customer trust. While the insignificant influence means that the level of trust in the statement that the handling of the problem affects the trust is still in doubt, so that increasing the handling of the problem may not necessarily increase customer confidence. This can occur due to the level of education of the majority of customers who were educated last at the undergraduate or undergraduate level. Based on that 39 people out of 77 respondents had the latest undergraduate or strata level of education 1. A high level of education makes customers feel able to solve their problems independently, so that the improvement of problem solving done by the Bank BRI is not necessarily able to increase customer confidence. The results of this study differ from the findings in a study conducted by Hatane (2012) that handling conflicts / complaints has a significant positive relationship on trust. Such conditions could occur due to differences in location and research object.

The results of this study indicate that communication has a positive and significant role on commitment. A positive influence can be interpreted that communication has a direct role on customer commitment, while a significant influence means that the level of trust in the truth of the statement that communication has a positive role on commitment can be trusted. so that increased communication can affect customer commitment and decrease communication can affect customer commitment. This can be seen in the response of respondents who have been very good/high towards the BRI Bank who communicate directly in the form of providing information to customers. It can also be seen in the responses of respondents to the commitment which, on average, can be categorized as good. Therefore, the BRI Bank that communicates directly in the form of providing information to customers can make customers feel happy to visit BRI Bank Kendari city office and can increase customer feelings about a high sense of ownership of BRI Bank. 
The results of this study indicate that the handling of the problem has a positive and not significant role on commitment. A positive influence can be interpreted that the handling of problems has a direct role on commitment. While the insignificant influence can be interpreted that the level of confidence about the truth of the statement that the handling of the problem has a positive role on commitment is not so strong or is still in doubt that increasing the handling of the problem does not necessarily increase the commitment of the customer. Therefore it can be concluded that problem handling has an influence on customer commitment but problem solving is not necessarily able to increase customer commitment at Bank BRI.

The results of this study indicate that trust has a positive and significant role on commitment. Positive influence means that trust has a direct role on customer commitment. While significant influence means that the level of trust in the truth of the statement that trust has a positive role on commitment is high or can be trusted so that increasing trust can increase customer commitment and a decrease in trust can also reduce customer commitment. This can occur because of the respondents good/high responses to the statement that the company can be trusted because it is very concerned about customers leaving. The good response made respondent's statement about the statement that the customer was not affected by alternatives offered by other banks to be good too. The results of this study prove from what was delivered by Hasanuddin (2009) that commitment is created because each party trusts each other to get the expected value. Therefore, the results of this study indicate that the higher the customer's trust the more commitment the company will make to the company.

The results of this study indicate that communication has a negative and not significant role on loyalty. Negative influence means that communication has a non-directional role on customer loyalty. While the insignificant influence means that the level of trust in the truth of the statement that communication has a negative role on loyalty cannot be trusted or is still low so that increasing communication may not necessarily reduce customer loyalty. The results of this study reinforce the findings in the study of Laith \& Nahla (2010) and Widya et al (2017) which states that communication have a significant positive relationship to loyalty. This further reinforces the statement that the better communication will make customers more loyal.

The results of this study indicate that the handling of problems has a negative role and is not significant to loyalty. Negative influence means that the handling of the problem does not have a direct role on loyalty, while the role of insignificance can be interpreted that the level of trust in the truth of the statement that the handling of the problem has a negative role on loyalty that is not so strong or unreliable so that increasing the handling of the problem can only reduce loyalty or increase customer loyalty. This can occur due to the high level of customer education, namely the majority of BRI Bank customers who have a college degree. A high level of education makes customers feel able to solve their problems independently. So when there is an effort from the BRI Bank to solve the problems experienced by customers it can only reduce customer loyalty, but bias can also increase customer loyalty. The results of this study are different from the findings in the research of Moosavi et al (2013), Carvajal et al. (2011) and Gina \& Widyastuti (2013) which show that problem / conflict handling have a significant role on loyalty.

The results of this study indicate that trust has a positive and significant role on loyalty. Positive influence can be interpreted that the change in trust is in line with the change in loyalty, meaning that when trust increases, loyalty will increase and vice versa when trust decreases, loyalty will also decrease. While significant influence can be interpreted that the level of trust in the truth of the statement that trust has a positive role on loyalty is high or can be trusted. So it can be believed that increasing trust can increase loyalty and decreasing trust can reduce loyalty. This can occur because the response of respondents to trust can be categorized as good, while the response of respondents about the statement that the company can be trusted because it considers the interests of customers can be categorized very well. The high level of customer trust in the BRI Bank can make customers become loyal. The thing that respondent's response to loyalty can be categorized as good. The results of this study reinforce the findings in the research of Moosavi et al (2013); Gina \& Widyastuti (2013) which show that trust have a significant role on loyalty.

The results of this study indicate that commitment has a positive and significant role on loyalty. Positive influence can be interpreted that the change in commitment is in line with the change in loyalty, meaning that when commitment increases loyalty will increase and vice versa when commitment decreases loyalty will also decrease. While significant influence can be interpreted that the level of trust in the truth of the statement that commitment has a positive role on loyalty is high or can be trusted. So it can be believed that increasing commitment can increase loyalty and decreasing commitment can reduce loyalty. This can occur because the response of respondents to the commitment can be categorized as good, while the response of respondents about the statement that customers have a high sense of ownership of the BRI Bank can also be categorized as good. The results of this study difference from the findings in the study of Laith and Nahla (2010) which shows that commitment does not have a significant role on loyalty. But on the other hand, this study reinforces the findings in the study of Moosavi et al. (2013); Gina and Widyastuti (2013) which states that commitment has a significant role on loyalty.

\section{Conclusions}

Based on the results of research and discussion about the role of relationship marketing to increase customer loyalty at BRI Bank, Kendari City, Communication has a significant role to increase customer trust, this mean is better communication can increase customer trust. Problem handling has a not significant role to increase customer trust, meaning that increasing problem handling may not necessarily increase customer trust. Communication has a significant role to increase customer commitment, which means that increased communication can increase customer commitment. Problem handling has not significant role to increase customer 
commitments, meaning that improving problem handling does not necessarily increase customer commitment. Trust has a significant role to increase customer commitment, which means an increase in trust can be increase customer commitment. Communication has not significant role to increase customer loyalty, meaning that increased communication does not necessarily increase customer loyalty. Problem handling has not significant role to increase customer loyalty, which means that increasing problem handling does not necessarily increase customer loyalty. Trust has a significant role to increase customer loyalty, which means an increase in trust can increase customer loyalty. Commitment has a significant role to increase customer loyalty, meaning that an increase in commitment can be increase customer loyalty.

\section{References}

Alma, B., \& Hurriyati, R. (2008). Manajemen Corporate dan Strategi Pemasaran Jasa Pendidikan. Alfabeta Press. Bandung. Carvajal, A.S., Ruzzi, A.L., Nogales, A.F., \& Moreno, V.M. (2011). The Impact of Personalization and Complaint Handling on Customer Loyalty. African Journal of Business Management, 5(34), 13187-13198. https://doi.org/10.5897/AJBM11.1162

Cater, T., \& Cater, B. (2010). Product and Relationship Quality Influence on Customer Commitment and Loyalty in B2B Manufacturing Relationship. Industrial Marketing Management, 39(8), 1321-1333.

https://doi.org/10.1016/j.indmarman.2010.02.006

Chandra, G. (2002). Strategi dan Program Pemasaran, Edisi 1. Andi Offcet. Yogyakarta.

Dwi, S.P., Haryono, A.T., \& Warso, M.M. (2016). Pengaruh Relationship Marketing Terhadap Loyalitas Pelanggan Dengan Kepuasan Pelanggan Sebagai Variabel Intervening (Studi Empiris Pada BMT Bina Umat Sejahtera Lasem). Journal of Management, 2(2), 14-23.

Doney, M.P., \& Cannon, P.J. (1997). An examination of the nature of trust in buyer-seller relationships. Journal of Marketing, 61(2), 35-51. https://doi.org/10.2307/1251829.

Gina, H., \& Widyastuti. (2013). Pengaruh Relationship Marketing terhadap Loyalitas Pelanggan pada Nasabah Bank BTPN KCP Sepanjang. BISMA (Bisnis Dan Manajemen), 6(1), 67. https://doi.org/10.26740/bisma.v6n1.p67-76.

Griffin, J. (2003). Customer Loyalty: Menumbuhkan Dan Mempertahankan Kesetiaan Pelanggan. Erlangga Press. Jakarta.

Hasanuddin, B. (2009). Pemasaran Hubungan Pergeseran Pemikiran Paradigma Pemasaran Transaksional ke Pemasaran Hubungan. Tunggal Mandiri Press, Malang.

Hatane, S. (2012). Customer Relationship Marketing Pengaruhnya Terhadap Kepercayaan dan Loyalitas Perbankan Nasional. Jurnal Manajemen Pemasaran, 7(1). https://doi.org/10.9744/pemasaran.7.1.33-41.

Hurriyati, R. (2008). Bauran Pemasaran \& Loyalitas Konsumen. Alfabeta Press. Bandung.

Karsono. (2005). Pengaruh Kualitas Pelayanan Terhadap Loyalitas Konsumen dengan Kepuasan Sebagai Variabel Pemediasi. Jurnal Bisnis \& Manajemen, 5(2), 183-196.

Kotler, P. (2007). Manajemen Pemasaran. Edisi Milenium. PT Prehallindo. Jakarta.

Kotler, P. (2010). Manajemen Pemasaran. Jilid 2, Edisi Kesebelas. PT. Indeks Kelompok Gramedia. Jakarta.

Laith, A., \& Nahla, A.N. (2010). Investigate the Impact of Relationship Marketing Orientation on Customer Loyalty: The Customer's Perspective. International Journal of Marketing Studies, 2(1). https://doi.org/10.5539/ijms.v2n1p155.

Lestari, D.N. (2014). Pengaruh Relationship Marketing Terhadap Loyalitas Nasabah Tabungan Pada PT. Bank Muamalat Indonesia, Tbk Cabang Palu. e-Jurnal Katalogis. 2(1), 46-57

Maedah, F. (2016). The Effect of Relationship Marketing on Customer Loyalty (Case Study: Dairy Company Cale). International Business Management, 10(20), 112-131.

Moosavi, K.S., Peyman, P.H., Kashani, R.M., Daryayee, Y.J., \& Khosravian, A. (2013). Investigate The Relationship Between Advertising and Sales. Kuwait Chapter of Arabian Journal of Business and Management Review, 2(10), 43-48. https://doi.org/10.12816/0001247

Morgan, M.., \& Hunt, D.S. (1994). The Commitment-Trust Theory of Relationship Marketing. Journal of Marketing, $58(3), 20$. https://doi.org/10.2307/1252308.

Ndubisi, N.O. (2007). Relationship marketing and customer loyalty. Marketing Intelligence and Planning, 25(1), 98-106. https://doi.org/10.1108/02634500710722425.

Payne, A. (1993). The Essence of Services Marketing. Prentince Hall. International. UK.

Sundaramoorthy, K., \& Sachithanantham, V. (2016). Role Of Relationship Marketing On Customer Loyalty. International Journal of Recent Research Review, 1(3), 78-85.

Supardi, 2005. Metodologi Penelitian Ekonomi dan Bisnis, UII Press, Yogyakarta.

Supardi,2008. Strategi Pemasaran. Edisi Kedua. Penerbit Andi. Yogyakarta.

Widya, K., Achmad, F., \& Arifin, Z. (2017). Pengaruh Relationship Marketing Terhadap Loyalitas (Survei Pada Nasabah Tabungan Britama PT. Bank Rakyat Indonesia (Persero) Tbk. Kantor Cabang Gresik). Jurnal Administrasi Bisnis (JAB), 51(1), 121-133.

Yanita,W., \& Anik, W. (2014). Analisis Pengaruh Relationship Marketing Terhadap Loyalitas Pelanggan. Jurnal Ilmu \& Riset Manajemen, 3(6), 23-34.

Zeithaml, V. A., Bitner, M. J., \& Gremler, D. D. (2010). Services Marketing Strategy. In Wiley International Encyclopedia of Marketing. John Wiley \& Sons, Ltd. https://doi.org/10.1002/9781444316568.wiem01055. 